\title{
A revision of the genus Pulaeus Den Heyer, with descriptions of a new genus and four new Brazilian species (Acari: Prostigmata: Cunaxidae)
}

\author{
TATIANE MARIE MARTINS GOMES DE CASTRO ${ }^{1} \& \mathrm{JACOB}^{\mathrm{DEN}}$ HEYER $^{2}$ \\ ${ }^{1}$ Departamento de Fitossanidade, UNESP, Campus de Jaboticabal, São Paulo, Brazil, 14884-900. \\ E-mail: tatianemarie@yahoo.com.br \\ ${ }^{2}$ Setor de Zoologia, Departamento de Entomologia, Acarologia Agrícola, Escola Superior de Agricultura "Luiz de Queiroz", \\ Universidade de São Paulo, Piracicaba, São Paulo, Brazil, 13418-900.E-mail: jacob.den.heyer@gmail.com \\ South African address: Department of Zoology and Entomology, University of the Free State, P.O. Box 339, Bloemfontein . \\ Website:www.uovs.ac.za
}

\begin{abstract}
A new genus, Lupaeus gen. nov., is created to contain part of the described species in the genus Pulaeus Den Heyer. A key to the genera of the tribe Pulaeini, to which these two genera belong, and one auxiliary key to the species of Brazil and South Africa, are provided. Four new species, viz. Pulaeus myrtaceus sp. nov., P. quadrisolenidius sp. nov., Lupaeus lectus sp. nov. and L. lobidorsalis sp. nov. are described and figured. P. martini Den Heyer, 1981 is designated as type species for the new genus. New nomenclatural combinations are reported.
\end{abstract}

Key words: Bdelloidea, Cunaxoidinae, predatory mite, identification key, taxonomy

\section{Introduction}

Very little is known about the biology of the Pulaeus Den Heyer species. Walter \& Kaplan (1991) reported them feeding on larvae of rootknot nematodes (Meloidogyne spp.). About 26 species of Pulaeus Den Heyer are known all over the world. This is the first report of Pulaeus in Brazil, where very little is known about its diversity. In this revision a new genus, viz. Lupaeus gen. nov., is created to contain part of the described species in the genus Pulaeus Den Heyer. Due to lack of described detail the following species, indicated as belonging to Pulaeus, are indeterminable, P. parapatzcuarensis (Shiba), P. patzcuarensis (Baker \& Hoffmann), P. pseudominutus Shiba, P. payatopalpus Corpuz-Raros, P. subterraneus and P. zaherii ElBishlawy \& Rakha. Tseng (1980) described Neocunaxoides unguianalis and mentioned 5 setae on the palpal femurogenu which places it in any one of the two genera under discussion but its true generic position cannot be determined. Pulaeus trepidus Kuznetsov \& Livshits is regarded as a species of Scutopalus Den Heyer (Sergeyenko, 2009, personal communication).

\section{Material and methods}

The specimens considered in this study were collected from two natural ecosystems, viz. Atlantic Forest and "Cerrado", both in the State of São Paulo, Brazil, during the Biota Project (FAPESP 97/7099-0). The sample localities in the Atlantic Forest were: Cananéia, Pariquera-Açu, Piracicaba and São Pedro whereas those in the "Cerrado" were: Luis Antônio, Pirassununga and São Carlos. The mites were mounted in Hoyer's medium. Kethley's (1990) setal notation for the dorsal chaetotaxy, as adapted by Den Heyer \& Castro (2008), is followed; for appendages that of Den Heyer (1981a). The abbreviations and symbols used in this paper for the 